\title{
Learning Activities of the of Students in Peer-Jury Practices in the Architecture Design Studio
}

\author{
Rahman Tafahomi \\ Department of Architecture, School of Architecture and Built Environment, College of \\ Science and Technology, the University of Rwanda, tafahomi@gmail.com
}

\author{
Received: 21 May 2021; Revised: 16 June 2021; Accepted: 22 July 2021 \\ DOI: http://dx.doi.org/10.37905/aksara.7.3.795-814.2021
}

\begin{abstract}
The students learn through critical thinking and commenting on the design works of other students. This paper aims to demonstrate the learning process of the students in a peerjury activity through both mind engagement and practical activities in the architecture design studio. The methodology of the research was based on the qualitative methods with the application of semi-structured observation, photography, sketching, and graphical analysis techniques. The findings of the analysis reveal that the students participated in the peer-jury activity with five attitudes including passive, reactive, active, interactive, and engaged. The peer-jury groups' applied four approaches to comment on the peer presenters design outputs of including the design process, task response, idea of the design, and design outputs. In conclusion, the students learn through peers effectively to enhance their skills and abilities in a structured communication. The students improve critical thinking skills through practice, personalization, and communication.
\end{abstract}

\section{Keywords}

Architecture Design Studio, Peer-Learning, Students-Peer-Jury, Learning Outcomes, Practice and Activity

\section{INTRODUCTION}

Studies discuss widely the positive effects of the peer-tutor to develop the style of the students' thoughts in classrooms. For example, Lee highlighted that the students in the peer-tutor activity achieve an effective level of knowledge, skills, and interaction (Lee, 2005). In addition, another study referred to a large cluster of outcomes such as peer teaching of the curriculum, peer motivation, peer competition (Greenwood, Maheady, \& Delquadri, 2002), measurement, assessment, and cooperative activities among students (Lee, 2005).

The student-peer-review activity also mentions as a method with advantages including profound learning, active learning, and self-dependence, autonomy in the learning process (Ion, Barrera-Corominas, \& Tomàs-Folch, 2016). However, the study debuted on the results of the assessment of the students in the peer-leaning process (Tucker \& Reynolds, 2006), and another study highlighted the negative effects of the critic's assessments on the progress of the students in the studio (Smith, 2011).

Major parts of the architecture modules engage the students with practical activities in terms of skills development that differ from memorizing the content of the 
courses (Bailey, 2002). This activity takes the place in the studio based on the design process to lead the students for the acquisition of knowledge through mind development (Brown \& Renshaw, 2006) and critical thinking (Mindrup, 2014). In this regard, it is supposed that this research could explore the learning outcomes in the design studio through a peer-jury activity to engage the students in the thinking process similar to a jury, to express the critical points of view, and develop the design studio products.

There is a traditional limitation to apply peer learning in design studios. The study highlighted that there is a trend in some schools of art, design, and architecture to follow the apprenticeship style of teaching (D'Souza, 2007). In this style, the master of the atelier is the person in charge of leading the students for the redrawing, drawing, and design stages in the studio (Littmann, 2000; Madanovic, 2018; Drexler, 1975). This process links the students to the master of the studio as the only source of knowledge to evaluate the quality of teaching, learning, and assessment (Laroche, 2008).

Therefore, the research assumes that the creation of a peer-student-jury assignment perhaps strengthen the mind of students to think as a jury and increases collaboration between the students through peer learning in teamwork activities. In fact, the students learn to exercise different learning methods, skills, and abilities through a project in the fourth year of the study. Although the study reveals that the students follow the instruction without a clear idea for the self-conceptualization in the first year of the architecture program, they reach gradually to an abstract concept for design through activities in the fourth year of studies (Iyer \& Roberts, 2014).

The research questions are designed based on to investigate whether would the peer-jury position improves the learning process between the students. What do the students in terms of behaviours in the position of the jury? In addition, what kind of behavioural patterns do the students to facilitate the process of learning through the exercise? In this regard, the main goal of this research is to investigate the peer-jury activity in terms of peer assessment as a process of thoughts development of the students in the design studio. This course is supposed to run based on the studio to encourage the students to follow the design process than design-product to avoid memorizing (Bailey, 2002). It is supposed that asking the students to take the position of a jury, to critique on the quality of the project, enhances the level of the learning outcomes through evaluation of the students' production via jury-lens in terms of a peer activity. Although the students discuss in the whole semester to develop the project, seemingly enhancing the level of critical communication as an essential activity enriches the learning outcomes in the course. Therefore, 11 groups of the students arranged to design, critique, and comment on each other simultaneously in each session of the design studio. All the activities of the students in the position of peer-jury observed and recorded for analysis in terms of mind activities, communication practices, and learning outcomes in the experimental exercise.

In this logic, the research is designed based on a free grouping proposal to arrange the students a minimum of two and a maximum of four students in each group for the experiment exercise. It is supposed that putting the students' in-group could reduce the level of withdrawnness among the students in terms of the isolated, dissocialized, or rejected (Woolfolk, 2016), which the study revealed that the group activity could support the design outputs, presentation, and the judgement, and group mitigates the level of assertive and aggressive attitude (Tafahomi, 2020). 
AKSARA: Jurnal Ilmu Pendidikan Nonformal

P-ISSN 2407-8018 E-ISSN 2721-7310 DOI prefix $\underline{10.37905}$

Volume 07, (03) September 2021

http://ejurnal.pps.ung.ac.id/index.php/Aksara

\section{Arguments on the Students' Engagement in the Peer Activities}

Researchers concluded that the behavioural patterns in the classroom should take into consideration as a process than an event, which includes the verbal, nonverbal, and participatory activities (Seifert \& Sutton, 2009), which the engagement of the students mentioned as the key factor in effective learning (Chinn, 2011; Woolfolk, 2016). This engagement activity took the position in the psychological, social and environmental aspects of education specifically motivation, physical cooperation, and collaborative atmosphere in the classroom respectively (Williams \& Robert, 1997).

The studies emphasized the high level of influences peer students on the behavioural patterns of students in the school (Lee, 2005). For example, the study on the peer influences in the school and higher education demonstrated a high level of effects grounded on the mind sets of the specific roles, cooperation, and competition, which were majority self-made based on the cultural background (Woolfolk, 2016). Despite the influences predominantly limited to the self-expressional attitude such as dressing, slang, and behaviour in schools (Collins \& Steinberg, 2006), the influences in higher education is extended to the subjective aspects and grade gaining (Lee, 2005), cooperation, and competition specifically in research, conceptualization, and design phases.

In the architecture studio, the study has demonstrated that not only students receive a bulk of the comments to improve the drawing boards as communication, but also they are inspired by the works of other students to develop their mind and conceptualization in terms of peer influence (Tafahomi, 2020). Although the students applied the abstract idea to express their design solution for the specific project, commenting on the drawing boards enhanced the level of the design and detail through changing of the behaviours of the learner in the process of learning (Tafahomi \& Nadi, 2016).

Critical thinking is widely discussed as the key element in effective learning in higher education. For example, critical thinking was summarized by Seifert and Sutton as the process of questioning, evaluating, and reasoning objectively in any field of knowledge (Seifert \& Sutton, 2009). This approach was cited as a skill and attitude than knowledge, which is designed by both cognition and metacognition skills. Woolfolk (2016) explained this approach as a process of questioning, arguing, documenting, analysing, reasoning, contextualizing, and conceptualizing. Critical thinking is recommended in term of a culture of thinking than just a mechanical process (Perkins, Jay, \& Tishman, 1993; Woolfolk, 2016). Specifically, in the architecture field of the study, the critical thinking has included an unseparated relationship with the creative thinking as a process of creating an object through the divergent and convergent stages of conceptualizing, drawing, and designing (Lang, 1987; Laseau, 2000; Lawson, 2005).

For this reason, Moreno highlights that the application of the knowledge through a design activity changes the memorized information to skills and ability in terms of personalization of knowledge (Moreno, 2010). Therefore, the assessment of the students perhaps represents the level of effective learning, acquisition of knowledge, and particularly the application of knowledge in the real design project. The study recommended testing, measurement, and evaluation (Salkind, 2008) activities to evaluate the improvement of the practice patterns of the students. 
Salkind advocated that the behavioural changing process refers to the behavioural analysis through systematic observation of the behaviours of the learners under influences of the intended interventions as an external factor to evaluate the behavioural changing process in certain degree (Salkind, 2008). In other words, the studies demonstrated that students could learn from an open context of learning such as people, peer, and practice. This idea is theorized as the social learning theory, which emphasizing on the process of the observation, selecting, and learning new knowledge in the practices in daily life (Bandura, 1986). In fact, the previous experience influences the behaviours of the learner in current and future grounded on personal anticipations, which is represented through attitudes of the students in higher education (Orindaru, 2015).

The studies on the behavioural patterns of the students in the classroom addressed to the verbal, nonverbal, intended, and unintended communication (Neill, 1991; Collins \& Michaels, 2006; Guerrero, 2006; Seifert \& Sutton, 2009). Despite the studies emphasized on the verbal and intended communication in terms of the on-topic knowledge, nonverbal and unintended activities also are included important data for the behavioural analysis of the learners in the classroom. Figure 1 attempts to illustrate the correlation.

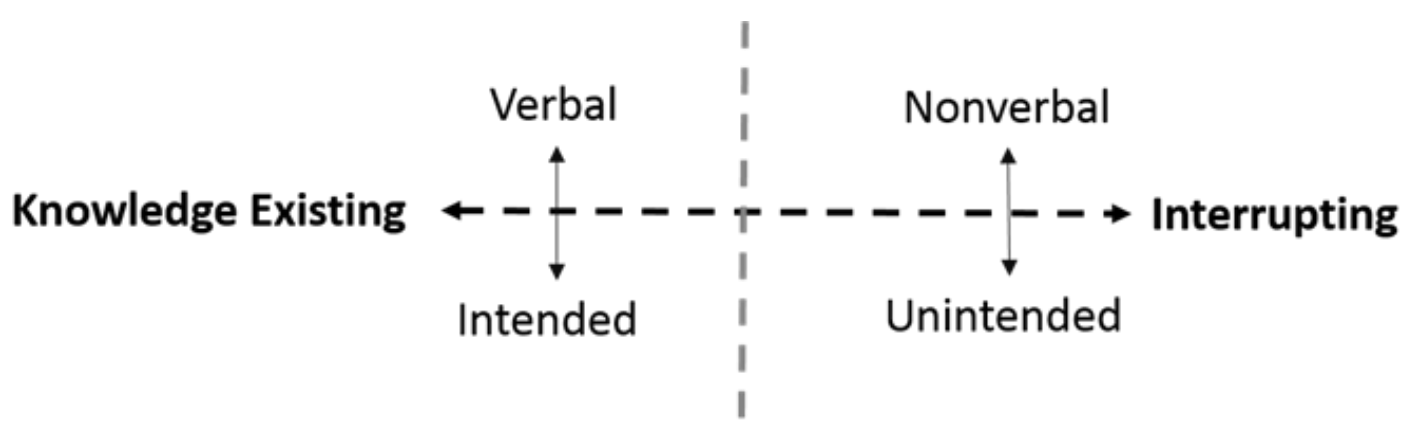

Figure 1: Interrelationship between Verbal, Nonverbal, Intended, and Unintended Communication

As a theoretical framework for the research, this research is arranged to test the ability of the lesson learning among the students through the peer-learning process. In this process, the students learn commenting on the other projects in the position of jury. This commenting develop the mind of the students to deal with the architectural critics as part of the design process. Therefore, the comments of the jury are supposed to change the design activities among the students in term of the application of the knowledge in the behavioural patterns. Figure 1 demonstrates relationships between styles of the communication, which are illustrated in four categories including verbalintended, verbal-unintended and nonverbal-intended, nonverbal-unintended. In a detailed view, verbal-intended communication makes explicit and on-topic comments and discussion based on the existing knowledge, which is the expectation of the educational system. However, on the opposite side, verbal-unintended communication results in an interrupted activity. In fact, unintended communication takes the position on an off-topic question or confusion, which needs to explain to create a new image of 
arrangement. Figure 2 attempts to conceptualize the correlation between those styles of communications.

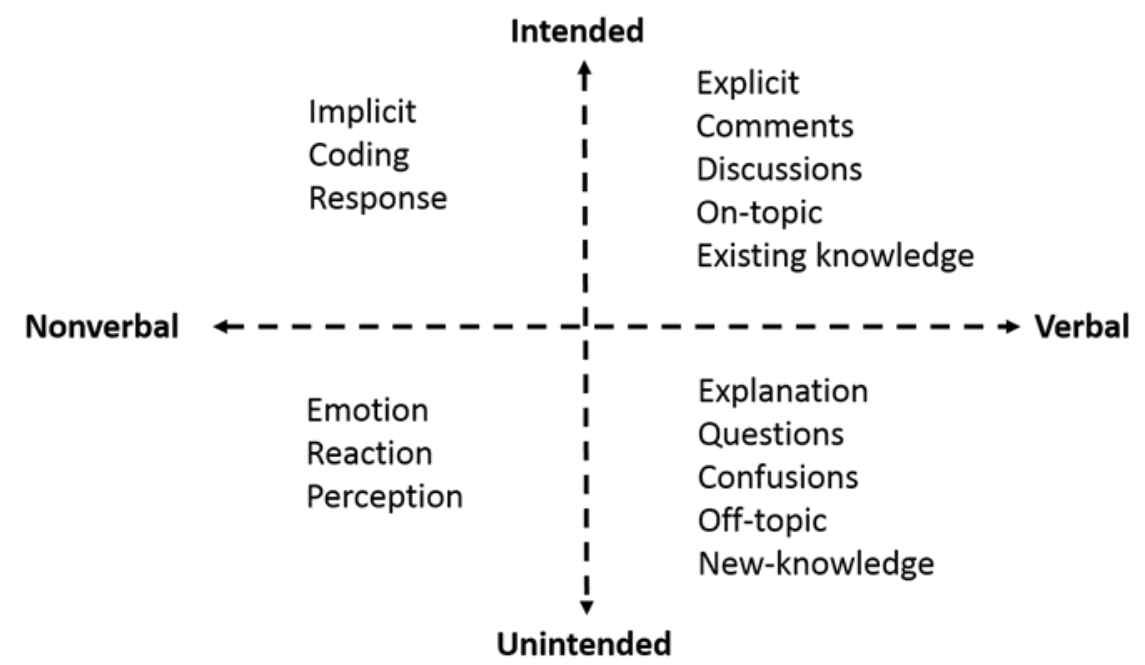

Figure 2: Correlations between styles of communications

Figure 2 attempts to illustrate intended-nonverbal and unintended-nonverbal communication in a classroom. In detail, the intended-nonverbal implies those physical gestures included specific meaning for the students to respond to the activity in the classroom such as non-eye-contact, making busy hands and eyes, and dreaming. Those nonverbal communications indicate the classroom environment and the context of the activity. In addition, the nonverbal-unintended activities could also present the perceptual factors in the classroom grounded on the emotion and reaction of the students.

\section{METHOD AND MATERIALS}

The methods and material part is included the essential segments to draw the methods of the research such ad methodology, research design, research process, data and sample, time and location, and limitation and implication in following parts.

\section{Methodology}

The applied methods in the similar research based on the students' behaviours in design studio included a wide range of the methods. Despite the quantitative method was applied to measure many topics in social science (Vaus, 2002) and steam (Silva, 2014) such as the opinion of the students about the educational environment (Yang, Becerik-Gerber, \& Mino, 2013), the qualitative methods have been applied mostly in the behavioural studies (Cohen, Manion, \& Morrison, 2007). The studies applied the observation (Neuman, 2006; Cohen, Manion, \& Morrison, 2007), interview (Hemyari, et al., 2013), photography (Tafahomi, 2020; 2021), and simulation with the graphical representation (Tafahomi, 2020; 2021), and phenomenology (Iyer \& Roberts, 2014). The studies adapted the research methods to size of the classroom with limited number of the students to emphasize more on the quality of data through a qualitative research. For example, recently the studies applied the semi-structured observation and graphical 
analysis to record and analysis the behavioural patterns of the students in the different seating arrangement in the design studio (Tafahomi, 2020; 2021).

\section{Research Design}

The research applied qualitative method to observe the behavioural patterns of the students in the context (Groat \& Wang, 2002; Silverman, 2004). A structured (Marshall and Rossman, 2006), active (Neuman, 2006), and lengthy (Groat \& Wang, 2002) observation (Frankfort-Nachmias, Nachmias, \& DeWaard, 2014; Tafahomi, 2021) was applied in research to discover the behaviours of the students in the position of peerjury. The observation took the place in other research as an effective technique to observe, survey, and record the behavioural patterns, activities, social interaction (Niezabitowska, 2018; Tafahomi \& Nadi, 2020; Tafahomi, 2020). The studies applied photography and sketching for data collecting in the qualitative research (Tafahomi, 2021) although the study highlighted the limitation of photography in sensitive areas and recommended the sketching as an effective alternative (Tafahomi \& Nadi, 2020). The structured observation was applied for the data collection through notetaking, photographs on the specific interaction of the students, and sketches in term of the graphical analysis to represent the behavioural patterns in diagrams (Laseau, 2000; Tafahomi, 2021).

\section{Research Process}

In the first session of the class, the instructor asked the students to group the class into peer-students to form groups for both design activities and evaluate the projects. The grouping process was based on the students' selection without any intervention of the instructor. It was supposed that the students have the right to change the composition of the group although none of them changed the group.

The observation took the place in the presentation times of the students in terms of the continuous assessment testing process (CATs) as the formative assessments in the studio. To facilitate the engagement of the students in the peer-jury experimental exercise, each peer-jury group was invited to take the position on the front line of the classroom, close to the boards of the students' presentation, to comment on the presentation (row 3 in Table 1). The project for the design was included four small projects in the landscape design to practice theoretical knowledge through designing. The task of the student-presenter was included documentation techniques, frontage design, waterscape design, and courtyard design. However, the task of the peer-jury was commenting, criticizing, and recommendations on the work of the presenter groups through communication (row 5 in Table).

The observation of the interaction between the group-presenter and the group-jury identified that the students were so passive to comment on the works of studentpresenters in the earlier sessions. Despite the groups of student-presenter communicated less sufficiently, when they took the position as the peer-jury, the communication declined dramatically. It was common trends among the groups of the students to concern about the comment, critique, and critic when they took the position as peerjury. In detail, the peer-jury groups presented with some behavioural patterns such as shy to communicate, quiet in a comment, and more tended to approve the presentation in the initial sessions. However, just two groups were exceptional in both student- 
presenter and peer-jury positions. Other students participated with fewer effects in the jury position.

According to the weak achievements in the peer-jury assessment, it was decided to involve a third factor as a catalyst to encourage the students more in the assessment process. Therefore, it was announced that the exercise is included minus and plus marks in terms of award-penalty for the peer-jury performance. The bonus marks changed the activities of the students in the position of jury significantly. In fact, the bonus mark encouraged the students to involve in the commenting in the presentations and develop their communication per sessions although two groups of the students participated in the exercise inefficiently.

The students followed their perceptions to comment based on the personal values than structured critiques in earlier sessions, which the instructor intervened to lead them for detailed comments in relation to the presentation. Therefore, the students reconstructed the comments through monitoring of the critical comments of the active peer-juries and the instructor to personalize their comments gradually based on structured, analytical, and effective styles. The students participated in the research in three positions including the students as presenter, the students' peer-jury, and the students' observers. It meant that one of the groups was in the position of the presenter, another group in the position of the peer-jury, and others in the position of the studentsaudience. After the first presentation, the position of all groups changed systematically (row 4 in Table 1).

\section{Data and Sample Specification}

Data of the research was combined form semi-structured observation, photographs, and sketches in the design studio. Data was extracted from 20 students including 17 male and 3 female students in the 4th year of study in architected undergraduate program who was passing the landscape design course. The activities of the students included three roles including as the student-presenter, the student-peerjury, and student-audience. The important behavioural pattern of the students in the position of the jury recoded as data for the analysis and interpretation. The behaviours were encompassed the talks, gesture, eyes contact, and physical movement of the students in the position of peer-jury. The instructor documented the behaviours of the students in the position of students-peer-jury through notetaking and the photographs in the weekly activity.

\section{Time and Location}

The research activity took the place in the second floor of the school of architecture and built environment (SABE), the University of Rwanda, where all studios located there (rows 1 and 2 in Table 1). The time of the observation was on Tuesdays morning from 9.00 to 12.00 . The exercise took the place for 12 weeks in the weekly classes of the landscape design, first semester of 2019-2020 academic year. 
Table 1

The Research Location and Process

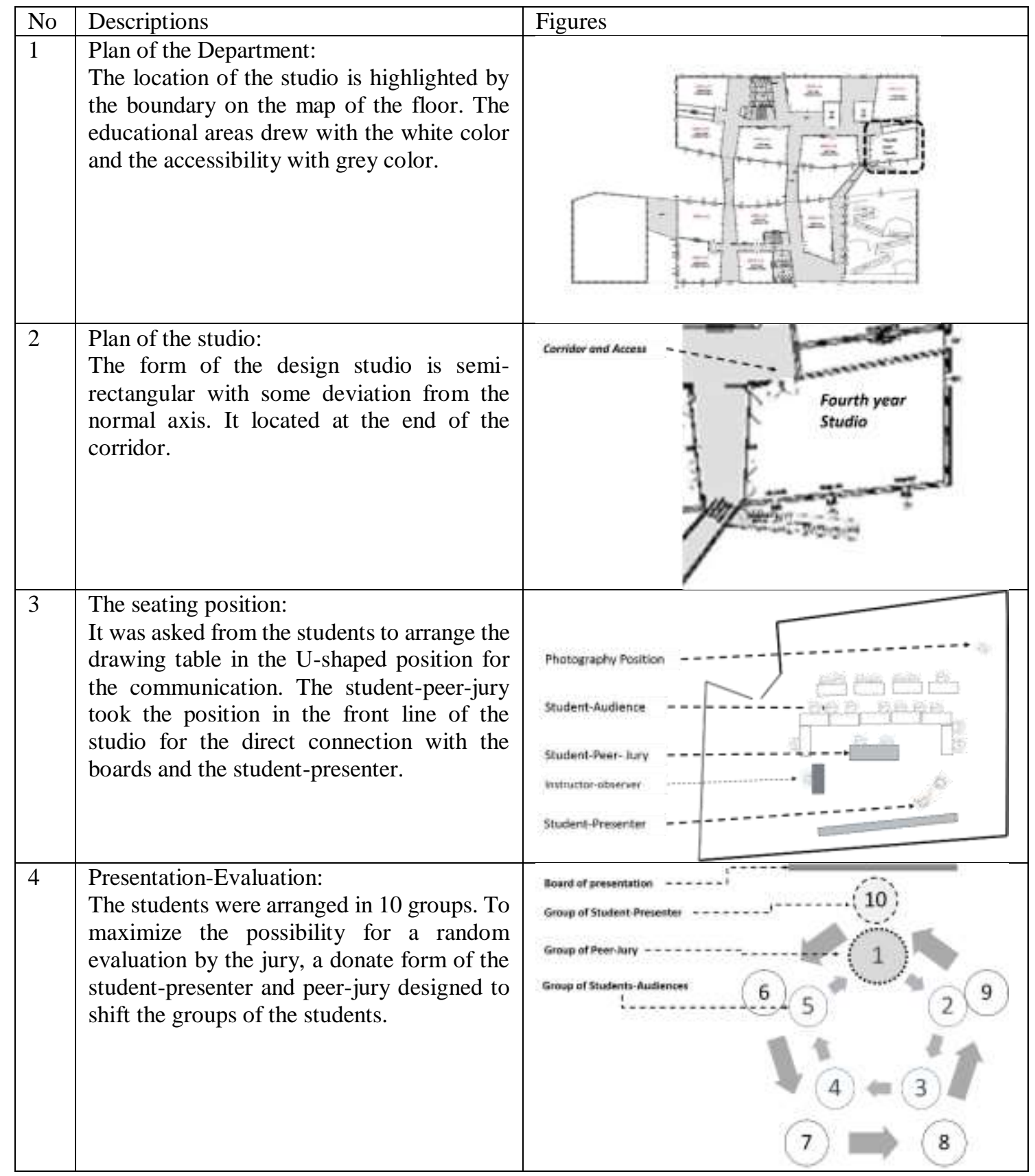




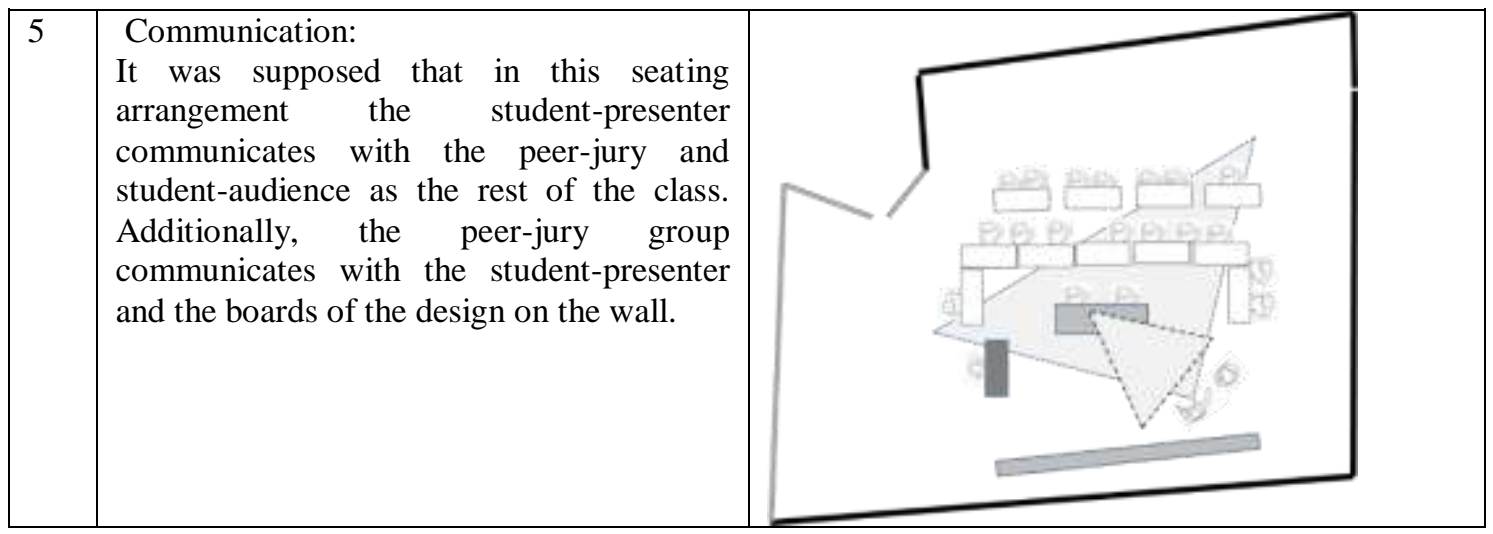

\section{Limitation and implication}

The students faced first time with the exercise and they behaved as their instructors behaved in the previous years of the study. The students did not include any experience for peer-jury activities and they learnt through continuous observation of the peer-jury in different sessions. Perhaps, involvement of other group of the students who had an experience in the activity resulted in other level of the engagement. Despite the level of the changing in the results could not be estimated although the possible of the change existed.

The research did not train the student for the job, task, and duty of a jury before of the exercise. The students behaved through recall the memories from observed critical sessions of presentation and lessons learnt from peer how to react in the position of jury. Despite the learning of the students was part of the exercise, the possible effects of training sessions for the students was existed for the results of the research although the level of the influences could be evaluated.

\section{RESULTS AND DISCUSSION}

\section{Result}

The students commented on the work of the student-presenter with highlighting four aspects of the design including evaluating the product, analysing the task response, investigating the perception of the students about the idea of design, and criticizing the process. The peer-jury groups communicated through a verbal style to present their evaluation on the works of the students, which articulated through explanation, description, and question. In addition to those verbal comments also, the jury pointed at the maps and drawing of the students with the point-fingers to indicated the specific aspect of their idea. In addition, the eyes contact and the gesture of the jury demonstrated their enthusiastic sense to the project. Nonetheless, two groups of the student-jury kept less active in the position including fewer eyes contact, distracted with any noise outside of the studio, and presenting general comments. Figure 3 attempts to portrait the behavioural patterns. 


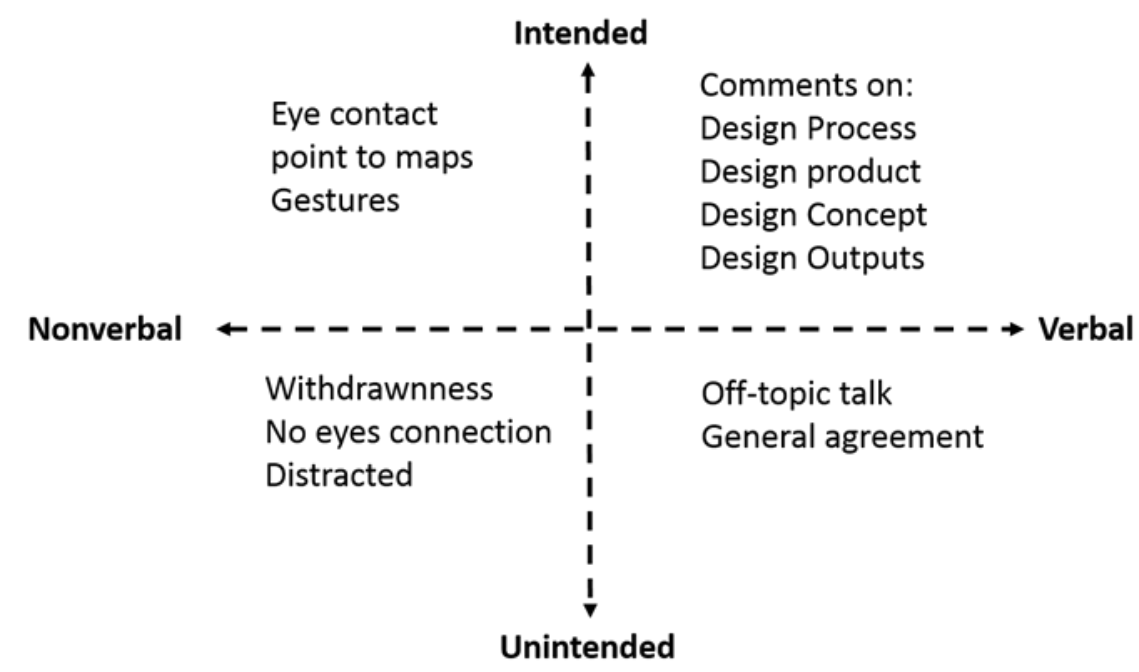

Figure 3: Interconnection between the Student-Presenter and Peer-Jury Groups

Furthermore, the exercise demonstrated five patterns of peer-jury' interaction with the student-presenters including passive, reactive, active, interactive, and engaged as shown in Table 2. First, the passive peer-jury paid less attention to the studentpresenter groups in the evaluation such as eyes contact, commenting, and criticizing. In fact, this group of juries faced the problem to notice, understand, and react to the student-presenter groups (row 1 in Table 2).

For both reactive and active groups of the peer-jury, the level of understanding and communication was sufficient in comparison to the passive group. In detail, the reactive groups commented on some general aspects of the presentation due to the level of progress, drawing boards, and final design outputs. However, the active group included a full-attention to the peer-jury, with communication, and the commenting on the design and drawings. They asked questions, requested for an explanation, and used of the hands-gesture to point for the specific aspects of the drawing to support their comments (rows 2 and 3 in Table 2).

The group of the interactives and engaged student-juries attempted to develop the design idea and drawing boards of the student-presenter through a detailed, specific, and oriented comments such as notes taking, full attention and eyes contacts, questioning, commenting, and dialogue with the group of the presenters and recommendations to enhance the quality of the designing. The engaged groups were interested to involve in the design process of the student-presenters to enhance the quality, which interactive groups were less (rows 4 and 5 in Table 2). 
Table 2

The Students' Reaction in the Position of Student-Peer-Jury

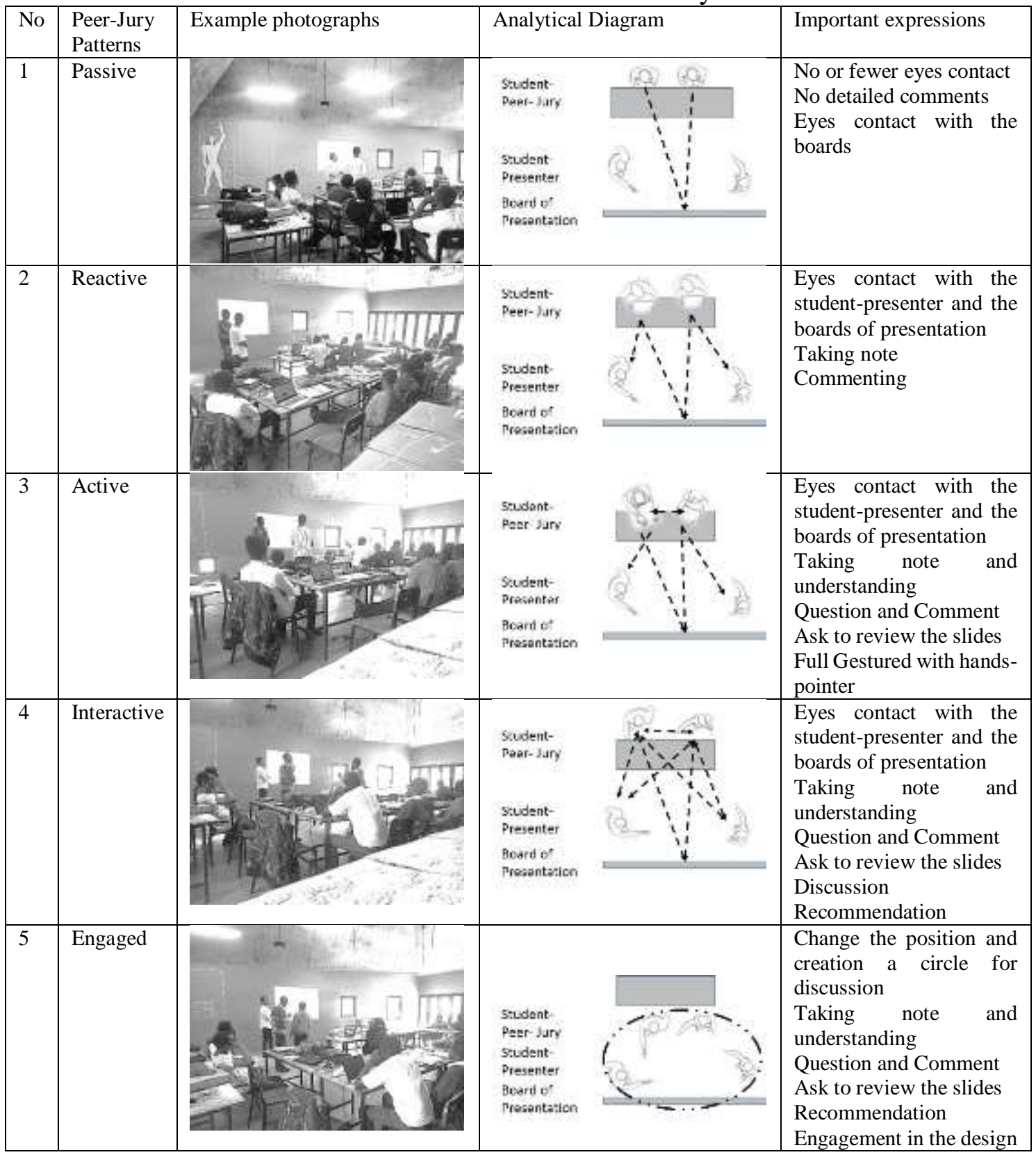

\section{Interpretation of Results}

The results of the exercise demonstrate that the students change their style of thoughts and learning based on experience, exercise, and practice. In fact, the process of performance reveals a continuous process of progress among the students from the low-level of interaction and communication to a high level. The students learn from peer-students to perform as a critical jury and an effective evaluator through repetition in different sessions of the class. Despite the fact that the results illustrate that the students believed their role as a jury progressively, and with increasing the self-steam 
of the students in the position, the level of the effectiveness of the comments is enhanced.

The students develop both verbal communication and behavioural interactions by switching of the positions between the student-presenter, student-peer-jury, and student-audience. In detail, the students learn to acquire new knowledge through the activities in the studio, which modify both styles of thinking and behaving as the internal and external behavioural patterns. The students learn and borrow from peer-groups some significant aspects, which emphasize the intellectual development in the exercise such as logical explanation, deep perception about the project, utilizing the creativity and innovation in works. The groups of the students demonstrate the application of the lessons learnt through verbal-intended style in the presentation, communication, and interaction, which is illustrated in Figure 4.

In addition, the students present a wide arrange of the behavioural changes as the lessons learnt in the exercise. Those lessons learnt also result in effective outputs in the process of the application of the knowledge in the design particularly conceptualizing, revising, reviewing, and re-editing activities. The results of the reciprocal interaction between mind development and the behavioural change enhance the progress of the architectural objectives such as drawing, designing, and detailing practices. Figure 4 arranges the learning outcomes of the exercise in a diagram that illustrates the verbal, behavioural, and internal and external modifications in terms of the mind and physical engagement.

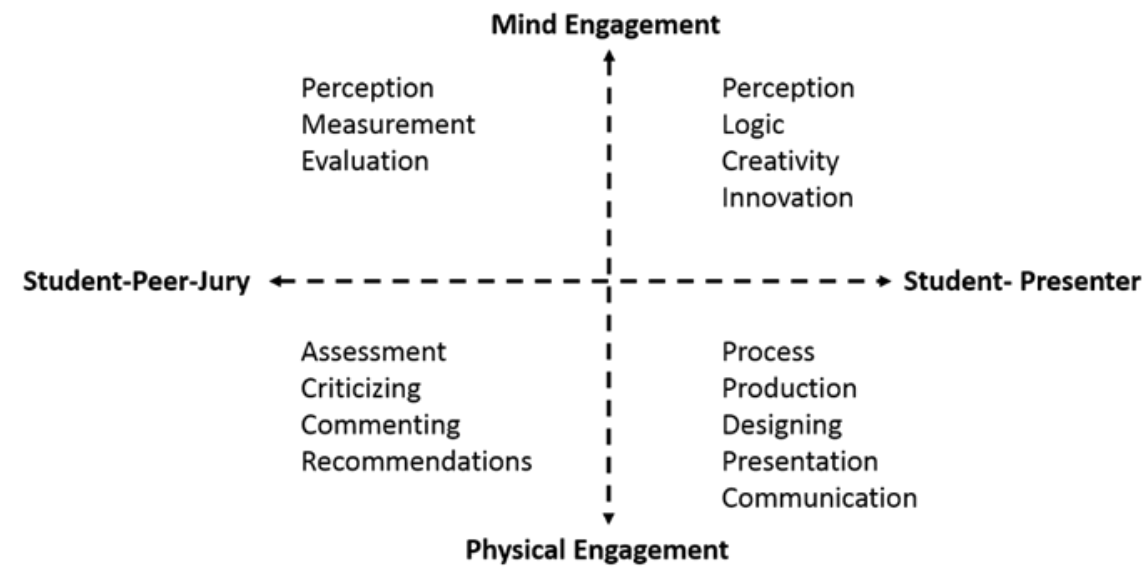

Figure 4: the Verbal and Behavioural Progress of the Students

In addition, Figure 5 attempts to demonstrate better the relationship between the comments of the students in the position of the jury and the effects on the students in the exercise in a nonlinear process. According to Figure 5, the level of reciprocal effects is more significant between the student-presenter and student-peer-jury groups. In this diagram, the level of the mastery of the instructor is reduced when the level of the peer influence enhanced. Seemingly, could observe a shifting from teacher-centre to students-centre activities in the studio. 


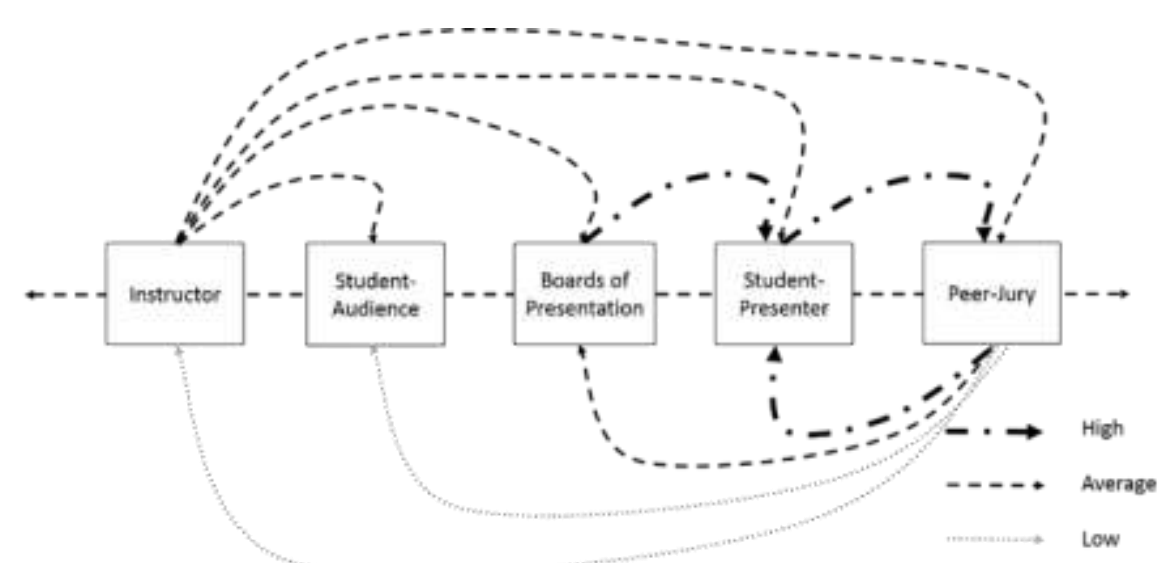

Figure 5: the Level of the Effectiveness of the Exercise between the Participants

The results identify that the students need to both internal and external motivation factors for the progress. The motivation factors influence the students through changing the level of critical thinking and physical reaction to the activity. Although two active groups of the students continue on the high level of the interaction, the level of the progress of other groups improved effectively based on the motivations. In detail, the competition on both harvesting more marks and archive to the position of an effective group of the jury to lead other students are two internal and external factors to progres $s$ the quality of the design in the studio. Therefore, despite the fact that the exercise started with more passive and reactive groups in the initial stages, with the progress of the activities they changed into active, interactive and engaged groups of the peer-jury.

\section{Discussion}

The results of the research demonstrated a changing process of the students' behaviours similar to the previous studies such as (Davies, 2004; Hamalainen, Hyyrynen, Ikonen, \& Porras, 2011; Moore \& Teather, 2013; Double, McGrane, \& Hopfenbeck, 2020) through the peer-learning activities. The students developed the style of thoughts through the exercise. They learnt how to apply different aspects of the communication such as phrases, professional words, and reformulation of the idea in an academic structure from other groups of the students. This result was in the same alignment with the results of Seifert and Sutton, which highlighted the progress of the students as a process than an event (Seifert \& Sutton, 2009). In addition, this learning outcome could cover the critics on the structure of the studio as an inflexible process (Drexler, 1975; Littmann, 2000; Madanovic, 2018). Apparently, the students did not just impersonate the style of other students rather than they attempted to personalize the verbal and behavioural communication to present their lessons learnt through interaction. Therefore, all roles of the students were effective on the process learning, testing, and evaluation similar to the finding of Salkind (2008).

Despite the fact that the level of participation was depended on the motivation and personality of the students in different activities, similar to the finding of Orindaro, they were ready to shift the orientation from the passive to an active participant in specific condition (Orindaru, 2015). In detail, the marking system increased the level of participation the students in both student-peer-jury and student-audience in the same alignment with the findings of McClean and Hourigan (2013). Seemingly, the external 
factor as the encouragement by bonus marks changed the attitude from passive to active in the same alignment to the other researches (Greenwood, Maheady, \& Delquadri, 2002; Lee, 2005). Figure 6 attempts to represent this specification of the participants between the verbal-behavioural and passive-active relationships.

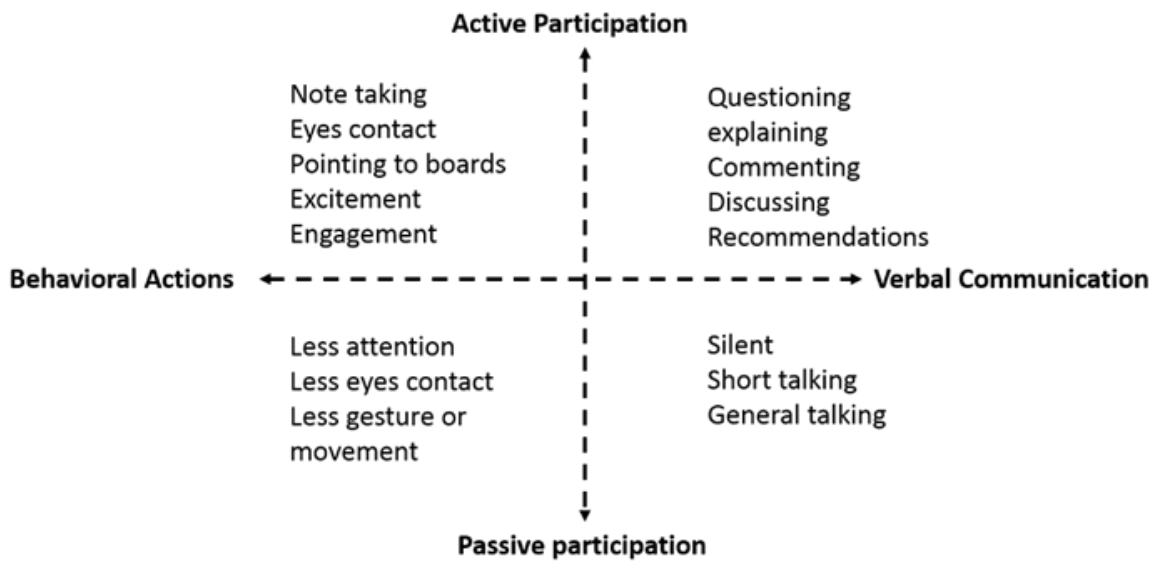

Figure 6: the Students' Participation in the Exercise from Passive to Active

In addition, the critical thinking outcome was the important expectation in the task, which the students represented effectively criticizing, commenting, and evaluating design outputs of other students. In detail, the students in the different position demonstrated a cognitive process of the acquisition of knowledge in terms of learning activity (Brown \& Renshaw, 2006) through critical thinking in both design and evaluation, which emphasized by Mindrup (2014). The outputs of the students' activities were represented through two main approaches in the architectural design in terms of either design as a process or design as a product. They learnt progressively how to recognize the differentiation of the quality of design in the works of the other students and represented their point of view in an enhanced stage. This process highlighted that the students learn to think profoundly about the design process as mentioned in other studies (Lang, 1987; Laseau, 2000; Lawson, 2005) as the process of design development. Seemingly, this achievement is similar to studies such as (Perkins, Jay, \& Tishman, 1993; Woolfolk, 2016), which formulated the thinking as a culture of thinking. Figure 7 demonstrates this specification. 


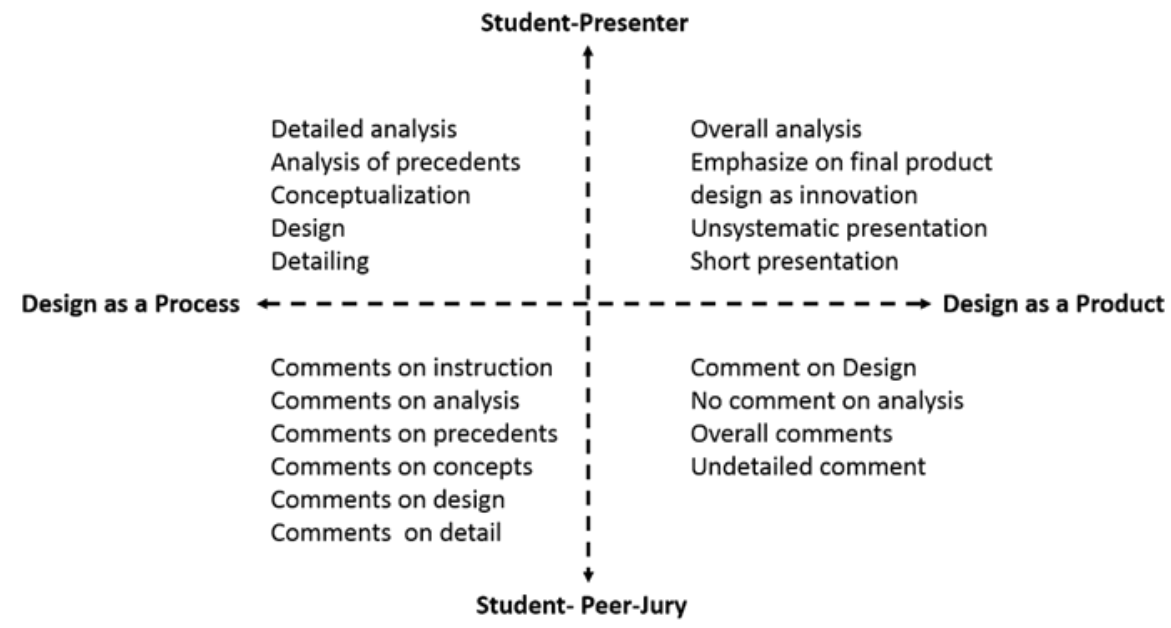

Figure 7: Critical Thinking of the Students in terms of Criticizing on the Design

Significantly, the peer-students have had a fundamental effect on the learning outcomes. The peer-jury perception and interpretation challenged the mind of groups of the student-presenters, which mentioned as autonomy in learning by Ion and colleagues (Ion, Barrera-Corominas, \& Tomàs-Folch, 2016). In detail, switching the positions of the students to peer-jury groups enhanced level of comments in terms of validity and variety through personalization of the comments as mentioned in other studies (Chinn, 2011; Woolfolk, 2016). In fact, it was a process of creativity and innovation, which created a circle of the receiving comments, reacting, personalizing, applying, and representing that other studies discussed (Perkins, Jay, \& Tishman, 1993; Lang, 1987; Laseau, 2000; Lawson, 2005). Certainly, the students followed their own perception in the preparation of the task, which varied from the instruction was expected, similar to studies such as (Hancock, 1995; Williams \& Robert, 1997; Salkind, 2008). Therefore, the self-perception and interpretation of the lessons were the most self-oriented aspects of the interaction between mind and activity among students in terms of the lessons learnt (Lee, 2005; Woolfolk, 2016). Figure 8 illustrates the interaction between the position of the students and their trends in the personalization of the instruction.

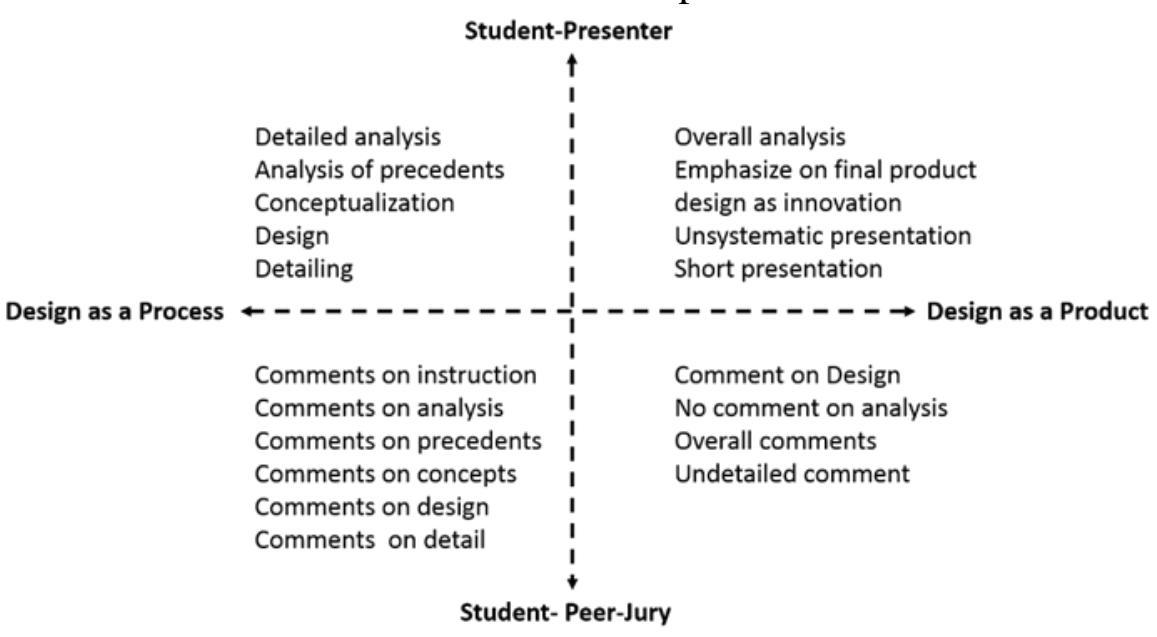

Figure 8: the Process of the Personalization the Instruction by the Students 


\section{CONCLUSION}

The research attempts to share the positive influences of putting the students in the position of the peer-jury. The positive results are revealed through the mind engagement of the students to personalize the lessons learnt through the application of knowledge in the activities and practices. The students represented their lessons learnt through reformulation, restructure, and modification of the comments, critics, and the suggestions in different phrases and sentences, which emphasized the verbal-intended activities in the exercise. They also applied the comments in the design process to enhance the design outputs. This output could highlight the positive effects of the practice and activity in the personalization of knowledge in the design studio.

The exercise reveals that the students are in the different level of the expressional attitudes to articulate their own ideas in the position of the peer-jury. In fact, the students react in the position from the passive to the engaged jury, which demonstrates a different process of the learning activity. This result highlights explicitly that the learning process is a personal journey with individual achievement among the students. It means despite the education system of the department has influenced the attitude; the cultural norms and the contextual influences play a significant role to form the performance.

The results of the exercise demonstrate that the students learn through the peer-jury to comment on the design outputs, presentation, and communication of the studentpresenter groups in three styles including process, product, and task response. Although peer-jury activity improves the analytical and critical thinking among the participants, the exercise influences differently on the behavioural patterns of the students. Therefore, the critic and peer-review training is part of the wider perspective of the learning activity in the context of education. It means peer-jury exercise supports constructing a culture of critical thinking in the studio.

Communication and presentation skills of the students change through exercises. The results demonstrate the progress of the students in both communication and presentation from the withdrawnness to the communicative participant. It is important to highlight that the behaviours of the participants approve the positive effects of the grouping work, teamwork production, individuality in the group, and construction of their own style of learning in a peer-learning environment.

\section{REFERENCES}

Bailey, S. (2002). Student approaches to learning in fashion design: a phenomenographic study. Art, Design \& Communication in Higher Education, 1(2), 8195.

Bandura, A. (1986). Social foundations of thought and action: A social cognitive theory. Englewood Cliffs, NJ: Prentice-Hall.

Brown, R., \& Renshaw, P. (2006). Positioning students as actors and authors: A chronotopic analysis of collaborative learning activities. Mind, Culture, and Activity, 13(3), 247-259. doi:10.1207/s15327884mca1303_6

Chinn, C. A. (2011). Educational psychology: Understanding students' thinking. Rutgers University: New Jersey.

Cohen, L., Manion, L., \& Morrison, K. (2007). Research methods in education. New York: Routledge. 
Collins, J., \& Michaels, S. (2006). Speaking and writing: Discourse strategies and the acquisition of literacy. In J. Cook-Gumperz, The social construction of literacy (pp. 245-263). New York: Cambridge University Press.

Collins, W. A., \& Steinberg, L. (2006). Adolescent development in interpersonal context. In W. Damon, R. Lerner, \& N. Eisenberg, Handbook of child psychology: Vol. 3. Social, emotional, and personality development (pp. 1003-1067)). New York, NY: Wiley.

D'Souza, N. (2007). Design intelligences: A case for multiple intelligences in architectural design. International Journal of Architectural Research, 1(2), 15-43.

Davies, P. (2004). Don't write, just mark: the validity of assessing student ability via their computerized peer-marking of an essay rather than their creation of an essay. ALT-J; Research in Learning Technology, 12(3), 261-277. doi:10.1080/0968776042000259573

Double, K. S., McGrane, J. A., \& Hopfenbeck, T. N. (2020). The impact of peer assessment on academic performance: A meta-analysis of control group studies. Educational Psychology Review, 32, 481-509. doi:10.1007/s10648-019-09510-3

Drexler, A. (1975). The architecture of the Ecole des Beaux-Art. New York: The Museum of Modern Art.

Frankfort-Nachmias, C., Nachmias, D., \& DeWaard, J. (2014). Research methods in the social sciences (8 Ed.). New York: SAGE Publisher Ink.

Greenwood, C. R., Maheady, L., \& Delquadri, J. (2002). Classwide peer tutoring programs. In M. R. Shinn, H. M. Walker, \& G. Stoner, Interventions for academic and behavior problems II: Preventive and remedial approaches (pp. 611-649). Bethesda, MD.

Groat, L., \& Wang, D. (2002). Architectural research methods. New York: John Wiley \& Sons INC.

Guerrero, L. (2006). Nonverbal communication in close relationships. Mahwah, NJ: Erlbaum.

Hamalainen, H., Hyyrynen, V., Ikonen, J., \& Porras, J. (2011). Applying peerreview for programming assignments, international. Journal on Information Technologies \& Security, 1, 3-17.

Hancock, J. (1995). The interpretive turn: Radical hermeneutics and the work of architecture. ACSA Annual Meeting History Theory Criticism, (pp. 183-188). New York.

Hemyari, C., Zomorodian, K., Ahrari, I., Tavana, S., Parva, M., Pakshir, K., . . . Sahraian, A. (2013). The mutual impact of personality traits on seating preference and educational achievement. European Journal of Psychological Education, 28, 863-877.

Ion, G., Barrera-Corominas, A., \& Tomàs-Folch, M. (2016). Written peer-feedback to enhance students' current and future learning. International Journal of Educational Technology in Higher Education, 13(15), 1-11. doi:10.1186/s41239-016-0017-y

Iyer, A., \& Roberts, A. (2014). A phenomenographic study in understanding architecture students' approaches to learning the coursework of architectural design. Journal for Education in the Built Environment, 9(1), 89-109. doi:10.11120jebe.2014.00010

Lang, j. (1987). Creating architectural theory: The role of the behavioural sciences in environmental design. New York: Van Nostrand Reinhold.

Laroche, D. (2008). The relationship between the Beaux-Arts school and the French school at Athens. 100 years with Danish architect at l'École française d'Athènes, 
Monographs of the Danish Institute at Athens. 13, pp. 11-17. Athens: Danish Institute at Athens.

Laseau, P. (2000). Graphic thinking for architects and designers (3 Ed.). New York: Wiley.

Lawson, B. (2005). How designers think: The design process demystified (4 Ed.). Oxford: Oxford Press.

Lee, S. W. (2005). Encyclopaedia of school psychology. Thousand Oaks, California: Sage Publications.

Littmann, W. (2000). Assault on the Ecole: Student campaigns against the Beaux Arts, 1925-1950. Journal of Architectural Education, 53(3), 159-166.

Madanovic, M. (2018). Persisting Beaux-Arts practices in architectural education: History and theory teaching at the Auckland school of architecture, 1927-1969. Interstices Auckland School Centenary Special Issue, 9-24.

Marshall, C., \& Rossman, G. B. (2006). Designing qualitative research. New York: SAGE Publications.

McClean, D., \& Hourigan, N. (2013). Critical dialogue in architecture studio: Peer interaction and feedback. Journal for Education in the Built Environment, 8(1), 35-57. doi:10.11120/jebe.2013.00004

Mindrup, M. (2014). Translations of material to technology in Bauhaus architecture. Wolkenkuckucksheim Internationale Zeitschrift zur Theorie der Architektur, 19(33), 161-172. Retrieved from cloudcuckoo.net/fileadmin/issues_en/issue_33/article_mindrup.pdf

Moore, C., \& Teather, S. (2013). Engaging students in peer review: Feedback as learning. Issues in Educational Research, 23(2), 196-211. Retrieved from https://ro.ecu.edu.au/ecuworks2013/9

Moreno, R. (2010). Educational psychology. Hoboken, NJ: John Wiley \& Sons, Inc.

Mulder, R. A., Pearce, J. M., \& Baik, C. (2014). Peer review in higher education: Student perceptions before and after participation. Active Learning in Higher Education, 15(2), 157-171. doi:10.1177/1469787414527391

Neill, S. (1991). Classroom nonverbal communication. New York: Routledge.

Neuman, W. L. (2006). Social research methods: Qualitative and quantitative approaches. London: Pearson Education, Ink, Fifth Edition.

Niezabitowska, E. D. (2018). Research methods and techniques in architecture. New York: Routledge.

Orindaru, A. (2015). Changing perspectives on students in higher education. In P. E. Finance (Ed.), 22nd International Economic Conference - IECS 2015 "Economic Prospects in the Context of Growing Global and Regional Interdependencies", IECS 2015. 27, pp. 682 - 691. Elsevier.

Perkins, D. N., Jay, E., \& Tishman, S. (1993). New conceptions of thinking: From ontology to education. Educational Psychologist, 28, 67-85.

Salkind, N. J. (2008). Encyclopaedia of educational psychology. London: SAGE Publications Ltd.

Seifert, K., \& Sutton, R. (2009). Educational psychology. Zurich, Switzerland: The Global Text Project. 
Silva, E. A. (2014). Quantitative methods' expertise - a diverse landscape in Europe and around the world. In E. A. Silva, P. Healey, N. Harris, \& P. V. Broeck, The Routledge handbook of planning research methods (pp. 251-254). New York: Routledge.

Silverman, D. (2004). Qualitative research: Theory, method and practice. New York: SAGE Publications Ltd.

Smith, C. (2011). Understanding students' views of the crit assessment. Journal for Education in the Built Environment, 6(1), 44-67.

Tafahomi, R. (2020). Educational outcome of students' group-table arrangement for collaboration in architectural thesis studio. LWATI: A Journal of Contemporary Research, 17(2), 22-46.

Tafahomi, R. (2021). Effects of the wall-faced seating arrangement strategy on the behavioural patterns of the students in the architecture thesis design studio. Asian Journal of Assessment in Teaching and Learning, 11(1), 85-97. doi:10.37134/ajatel.vol11.1.8.2021

Tafahomi, R. (2021). Qualities of the green landscape in primary schools, deficiencies and opportunities for health of the pupils. J. Fundam. Appl . Sci, 13(2), 1093 -1116. doi:10.43 14/jfas.v13i2.25

Tafahomi, R., \& Nadi, R. (2016). Modelling of thought in creation designing concept in urban design studio training. Prime Research on Education (PRE), 5(2), 821828.

Tafahomi, R., \& Nadi, R. (2020). Derivation of a design solution for the conservation of a historical Payab in the redevelopment of Doloeei, Gonabad. International Journal of Built Environment and Sustainability, 7(1), 1-9. doi:10.11113/ijbes.v7.n1.407

Tafahomi, R., \& Nadi, R. (2020). Insight into the missing aspects of therapeutic landscape in psychological centers in Kigali, Rwanda. Cities \& Health, 1-13. doi:10.1080/23748834.2020.1774035

Tucker, R., \& Reynolds, C. (2006). The impact of teaching models, group structures and assessment modes on cooperative learning in the student design studio. Journal for Education in the Built Environment, 1(2), 39-56.

Vaus, D. d. (2002). Surveys in social research (5 ed.). Crows Nest NSW, Australia: Routledge.

Williams, M., \& Robert, L. B. (1997). Psychology for language teachers. Cambridge: Cambridge University Press.

Woolfolk, A. (2016). Educational psychology. Boston: Pearson.

Xi, L., Yuan, Z., YunQui, B., \& Chiang, F.-K. (2017). An investigation of university students' classroom seating choices. Journal of Learning Spaces, 6(3), 13-22.

Yang, Z., Becerik-Gerber, B., \& Mino, L. (2013). A study on student perceptions of higher education classrooms: Impact of classroom attributes on student satisfaction and performance. Building \& Environment, 70(15), 171-188. 
AKSARA: Jurnal Ilmu Pendidikan Nonformal

P-ISSN 2407-8018 E-ISSN 2721-7310 DOI prefix 10.37905

Volume 07, (03) September 2021

http://ejurnal.pps.ung.ac.id/index.php/Aksara

814 AKSARA: Jurnal Ilmu Pendidikan Nonformal 